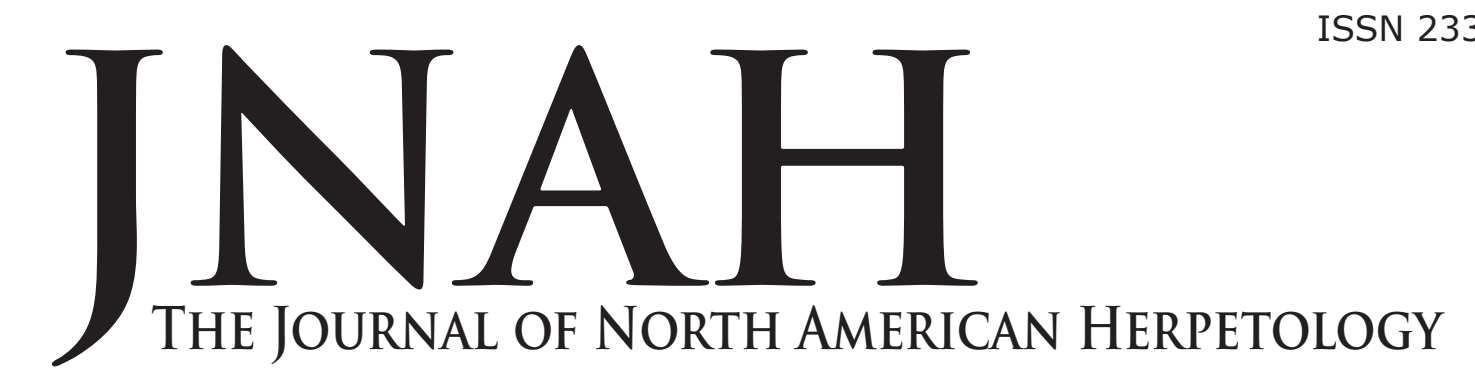

Volume 2014(1): 69-75 31 January 2014

jnah.cnah.org

\title{
CHEMICAL SIGNALS IN VERTEBRATE PREDATOR-PREY SYSTEMS INVOLVING COMMON MUSK TURTLES, STERNOTHERUS ODORATUS, AND THEIR PREDATORS
}

\author{
NEIL DAZET'1 AND DON MOLL² \\ ${ }^{1}$ Library Department, Brooklyn College, 2900 Bedford Avenue, Brooklyn, NY 11210, United States, \\ email: NDazet@brooklyn.cuny.edu \\ ${ }^{2}$ Department of Biology, Missouri State University, 901 S National Ave, Springfield, MO 65897, United \\ States, email: DonMoll@missouristate.edu
}

\begin{abstract}
Rathke's gland secretions (RGS) of Common Musk Turtles have a variety of proposed functions including predator deterrence and attraction, but experimental studies testing these hypotheses are lacking. This study used laboratory and field experiments to test whether RGS had attraction or repellent effects on two natural predators, the Cottonmouth (Agkistrodon piscivorus), and the Common Snapping Turtle (Chelydra serpentina). In a laboratory experiment, we examined latency to feed and consumption times for Cottonmouths offered RGS-treated minnows and control minnows. In a field study, we investigated the ratio of snapping turtles appearing in traps with and without RGS-treated bait. The latency to feed times for Cottonmouths offered RGS-treated minnows were not significantly different from those offered control minnows. However, prey consumption times for Cottonmouths feeding on RGS-treated minnows were significantly greater than those feeding on control minnows. These results suggest that the RGS may lengthen the time of a predation sequence, possibly allowing the turtle more time to escape from the predator. The number of snapping turtles appearing in traps with RGS-treated bait was significantly greater than the number of snapping turtles in traps without RGS-treated bait. These results support the predator attraction hypothesis, where the signal may attract additional predators that interfere with a predation event, providing an opportunity for the prey to escape.
\end{abstract}

Key Words. Agkistrodon piscivorus, Chelydra serpentina, Common Musk Turtle, Common Snapping Turtle, Cottonmouth, predator attraction, predator deterrence, predator-prey interactions, Rathke's gland, Rathke's gland secretions, RGS, Sternotherus odoratus

\section{INTRODUCTION}

In vertebrate predator-prey systems various signals have been identified which communicate potentially useful information between the interacting individuals and sometimes to other members of the vertebrate community. Chivers and Smith (1998) provided a review and prospectus of chemical alarm signaling in aquatic predator-prey systems, and noted the importance of distinguishing between signals that are emitted before and after the predator captures the prey. Chemical signals emitted by prey prior to capture are referred to as disturbance signals. Alternatively, chemical signals emitted by prey when the predator captures the prey are referred to as damage-released alarm signals. In aquatic systems, damage-released chemical alarm signals have been described for several vertebrate taxa including fishes (Smith, 1992; Mathis et al., 1995; Chivers et al., 1996) and amphibians (Hews, 1988; Marvin and Hutchison, 1995). These chemical alarm signals are analogous to auditory distress calls, which are given after the individual has been captured (Chivers and Smith, 1998). Auditory distress calls have been described for a wide variety of taxa, such as juvenile crocodilians (Staton, 1978), birds (Perrone, 1980; Hogstedt, 1983; Koenig et al., 1991), mammals (Sherman, 1985), and amphibians (Williams et al., 2000).

The function of a chemical alarm signal often changes the behavior of the signal's receiver. The receiver may be a conspecific, a heterospecific prey individual, the primary predator that initially stimulates the sender, or 
secondary predators (Smith, 1992). In the case where the signal receiver is another conspecific or heterospecific prey individual, the damage-released chemical alarm signal transmits information about predation risk, and may elicit antipredator behavioral responses (Weldon, 1983). Many vertebrate, aquatic taxa, including ostariophysan fishes, anuran amphibians, and caudate amphibians exhibit antipredator behavior in response to damage-released chemical alarm signals from conspecifics (Mathis and Smith, 1993; Chivers and Smith, 1998; Wisenden and Thiel, 2002; Hagman and Shine, 2008). In the case where the signal receiver is a predator, the damage-released chemical alarm signal can function as a predator attractant. In these predator-prey systems, the alarm signal may benefit the sender by attracting additional predators that disrupt the predation event, allowing the prey an opportunity to escape (Mathis et al., 1995). Previous studies have shown that damage-released chemical alarm signals from prey are attractive to a variety of vertebrate predators, including Gray and Blacktip Sharks (Tester, 1963), Northern Pike (Mathis et al., 1995; Chivers et al., 1996), and garter snakes (Halpern et al., 1986).

In predator-prey systems using a chelonian prey species, the Slider (Trachemys scripta) is frequently used as a model prey animal (Semlitsch and Gibbons, 1989; Britson and Gutzke, 1993; Green, 2006). In contrast, research using musk turtles (family Kinosternidae) as the focus of predator-prey studies has received relatively less attention (Jackson, 1990; Punzo and Alton, 2002) despite their trait of producing a strong, unpleasant smell when captured or roughly handled (Johnson, 2000); the context in which this chemical is released suggests that it could play a role in predator-prey interactions.

The Common Musk Turtle, Sternotherus odoratus, is a kinosternid turtle that owes its common and specific names to the odorous secretions that it produces. This small omnivorous species is widely distributed throughout lotic and lentic habitats from New England, Quebec and southern Ontario south to Florida and west to Wisconsin and central Texas (Ernst and Lovich, 2009). Sternotherus odoratus can be found in aquatic habitats with slow currents and soft bottoms, in rivers, streams, lakes, ponds, swamps, canals, bayous, and oxbows (Ernst and Lovich, 2009). Predators of juvenile Common Musk Turtles include raccoons (Procyon lotor), Bullfrogs (Lithobates catesbeianus), Cottonmouths (Agkistrodon piscivorus), and Common Snapping Turtles (Chelydra serpentina) (Ernst, 1986, 1992).

Common Musk Turtles secrete odorous fluid from four integumental glands, known as Rathke's glands, which are located beneath the anterior and posterior edges of the plastral bridges. All marine and many freshwater turtles possess Rathke's glands, which are specialized for the production and rapid expulsion of exocrine secretion (Ehrenfeld and Ehrenfeld, 1973; Eisner et al., 1977; Radhakrishna et al., 1989; Weldon and Tanner, 1990; Seifert et al., 1994). The discharged substance contains several aliphatic acids and four $\omega$-phenylalkanoic acids (phenylacetic, 3-phenylpropionic, 5-phenylpentanoic, and 7-phenylheptanoic) (Eisner et al., 1977).

In Sternotherus odoratus, Rathke's glands are present in both genders and are functional in juveniles and adults (Eisner et al., 1977). Although the exact function of the Rathke's gland secretions (RGS) is unknown, there are a number of proposed hypotheses. Using a classification system based upon the stages of a predation sequence (Endler, 1986), these hypotheses can be placed into three categories. Functions that do not occur during predation include the maintenance of the shell, and/or as a signal during courtship and mating (Ehrenfeld and Ehrenfeld, 1973; Rostal et al., 1991; Lewis et al., 2007; Monroe, 2009). Functions occurring before the subjugation phase of a predation sequence include use as a chemical aposematic warning (Eisner et al., 1977), and/ or a disturbance signal for intra-species communication (Ehrenfeld and Ehrenfeld, 1973; Lewis et al., 2007; Monroe, 2009). Lastly, when the RGS of S. odoratus are emitted during the subjugation phase of the predation sequence, and therefore analogous to damage-released chemical alarm signals, they may function as a predator repellent or a predator attractant.

We conducted a laboratory experiment and a field experiment to examine whether the RGS from S. odoratus function as a predator repellent or a predator attractant. For the laboratory experiment we used a predator of juvenile Common Musk Turtles, the Cottonmouth (A. piscivorus) (Ernst, 1992). The Cottonmouth is a heavy-bodied amphibious pit viper that co-occurs with $S$. odoratus in the southern and eastern United States including the southern portion of Missouri. Agkistrodon piscivorus inhabits swamps, marshes, bayous, the banks of streams with sand or mud bottoms, and the shores of ponds and lakes (Gloyd and Conant, 1990; Ernst 1992; Johnson, 2000). These aquatic environments are nearly identical to the preferred habitats of $S$. odoratus, whose activity mostly occurs within the highly vegetated, shallow littoral zone (Moll and Moll, 2004; Rowe et al., 2009). We investigated the behavioral (feeding) responses of Cottonmouths to Fathead Minnows (Pimephales promelas) that were topically covered with RGS from juvenile Common Musk Turtles. We compared behavioral responses (latency to feed and consumption time) of Cottonmouths that were offered minnows marked with RGS to Cottonmouths that were offered control minnows coated with dechlorinated water. Our hypothesis was that Cottonmouths feeding on the minnows marked with RGS would show increased latency to feed and increased consumption times in comparison to Cottonmouths offered control minnows.

For a field study, we targeted another predator of juvenile Common Musk Turtles, the Common Snapping Turtle (Chelydra serpentina). This species is a large aggressive turtle that occurs in aquatic habitats east of the Rocky Mountains in the United States. Much like S. odoratus, C. serpentina can be found in almost every type of fresh-

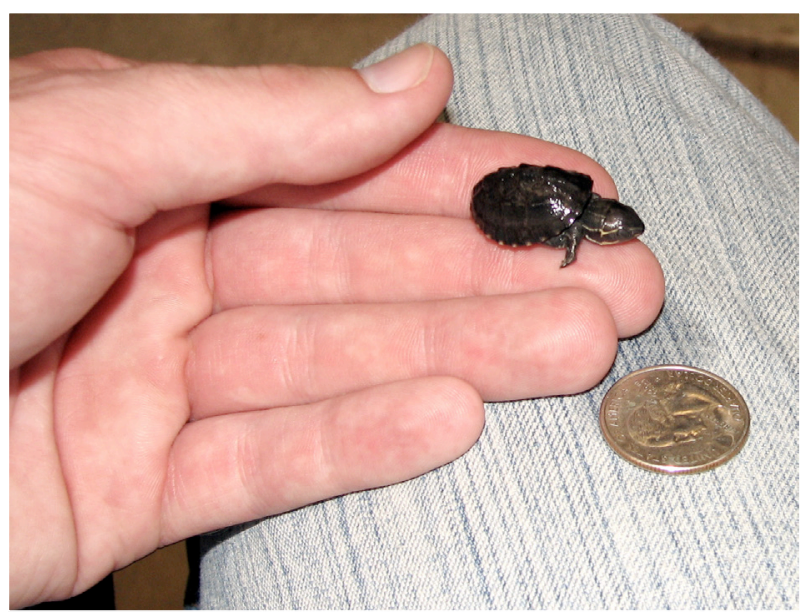

Figure 1. Juvenile Sternotherus odoratus. 
water environment but prefers a slow-moving waterway with a soft mud or sand bottom and abundant aquatic vegetation (Ernst and Lovich, 2009). The Common Snapping Turtle is an omnivore that consumes an extensive variety of prey items, including most aquatic taxa that it can fit into its jaws. In addition to carrion, $C$. serpentina eats plants, algae, snails, arthropods, worms, crayfish, insects, fish, salamanders, frogs and toads, small turtles, snakes, birds, and small mammals (Ernst and Lovich, 2009).

We investigated the behavioral responses of Common Snapping Turtles to trap bait that was either soaked in water containing RGS from Common Musk Turtles or in water without these secretions. Our hypothesis was that Common Snapping Turtles would appear more frequently in traps containing RGS-bait than traps containing control bait.

\section{MATERIALS AND METHODS}

Source of Chemical Cues - A total of 63 adult Sternotherus odoratus was collected from a population at Lake Springfield at the Springfield Conservation Nature Center in Greene County, Missouri. Turtles were collected between 16 May and 21 June 2006 under Missouri Department of Conservation wildlife collecting permit 13089 issued to Holly Monroe. Turtles were captured by hand and by use of sardine-baited mesh hoop traps (Legler, 1960). Turtles were separated by gender and kept in the lab in two metal stock tanks (265 L). Tank water was heated with UV lamps and contained rocks for basking. The stock tank housing females contained a terrestrial area composed of potting soil for basking and egg laying. Eight S. odoratus (Figure 1) were hatched in the laboratory and housed in a plastic container $(27 \mathrm{~L})$. Water in this container was filtered, heated with a UV lamp, and contained artificial plants and pieces of wood to simulate natural basking and cover objects. Turtles were fed Mazuri ${ }^{\circledR}$ commercial turtle pellets 2-3 times per week.

Rathke's gland secretions (RGS) from juvenile Common Musk Turtles were used in the laboratory experiment and RGS from adults were used in the field experiment. Both studies were conducted under the Missouri State University Institutional Animal Care and Use Committee protocol 2006S (21 November 2006) issued to the first author. Laboratory Experiment - Agkistrodon piscivorus were collected from the Wire Road Conservation Area near Crane in Stone County, MO between March and June 2006 under Missouri Department of Conservation wildlife collecting permits 13056 and 13113 . All snakes were appropriately housed, fed, and maintained for use in a

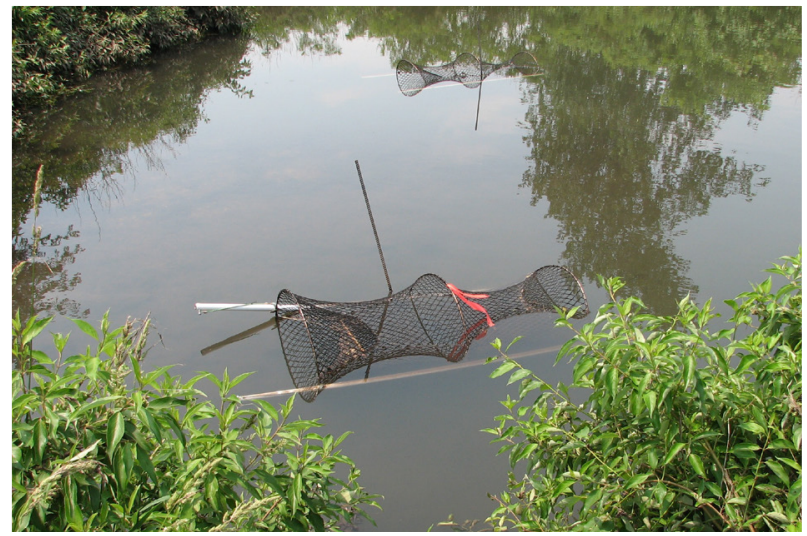

Figure 2. Pair of mesh hoop traps at field site. separate graduate research project (Mullich, 2007). Parturition of gravid females occurred in the lab in the fall of 2006. Snakes from these litters were housed individually in plastic containers $(34.3 \times 20.3 \times 12.7 \mathrm{~cm})$ with newspaper liner, a plastic hide structure, and a small dish used for food and water. Juvenile Cottonmouths were fed Fathead Minnows once every 7-12 days.

This experiment was conducted on 27 February 2007, and 10, 11 March 2007. Juvenile Cottonmouths were not fed 12-14 days prior to each trial. Each of the 12 snakes was tested twice, once with a control minnow (mean mass $\pm \mathrm{SE}=1.03 \pm 0.24 \mathrm{~g}$ ) and once with a treatment minnow (mean mass $\pm \mathrm{SE}=0.90 \pm 0.19 \mathrm{~g}$ ), in a random order of treatments using the same plastic container where they were housed and fed. Control minnows were topically coated with $11 \mathrm{~mL}$ of dechlorinated water. Treatment minnows were topically coated with 1 $\mathrm{mL}$ of RGS from juvenile Common Musk Turtles and 10 $\mathrm{mL}$ of dechlorinated water. To obtain RGS, the experimenter handled a juvenile Common Musk Turtle repeatedly (turned upside down, limbs nudged) until the smell of the odorous RGS was detected. The fluid discharged from the Rathke's glands was collected using a pipette, and immediately applied to a treatment minnow to prevent macromolecular degradation.

Latency to feed was measured as the time (in seconds) from the start of the trial when the minnow was placed in the water dish until the time when the snake secured the minnow in its jaws. Consumption time (in seconds) was measured as the time from when the minnow was secured until the time when the minnow was swallowed and no longer visible to the observer.

Data sets were created by calculating the difference between treatment and control times for individual snakes. Data from 4 snakes were not included because the snakes did not feed during one or both of the 60-minute trial periods. Comparisons on difference data were made using the nonparametric analogue of a paired t-test, the Wilcoxon test. Regression analysis was used to determine if minnow mass influenced consumption time (Minitab, 2010).

Field Experiment - Before travelling to the field site, RGS-bait (treatment) and non-RGS-bait (control) were prepared in the lab. Plastic containers $(5.7 \mathrm{~L})$ were filled with approximately $2 \mathrm{~L}$ of dechlorinated water. In preparation for the soaking of RGS-bait, 1 male musk turtle and 1 female musk turtle were handled repeatedly (turned upside down, limbs nudged) until the smell of the odorous RGS was detected by the experimenter, and then placed in one of the plastic containers. In prepara-

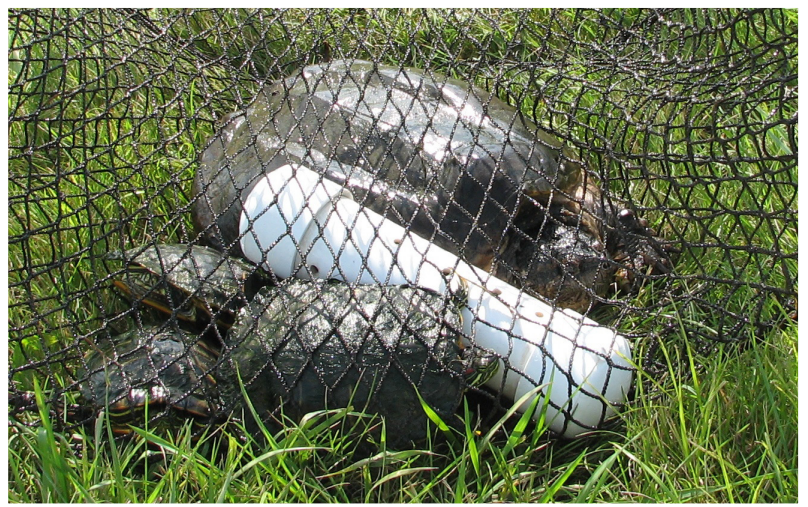

Figure 3. A bait guard, Chelydra serpentina, and Trachemys scripta. 
tion for the soaking of the non-RGS-bait, 1 male musk turtle and 1 female musk turtle were placed gently in one of the plastic containers, keeping handling time to a minimum. After $2 \mathrm{~m}$, turtles were removed and immediately replaced by the chicken gizzard bait, which was soaked in solution for $15 \mathrm{~m}$.

This study was conducted between 6 June and 15 June 2007 at the open slough habitat of the South Creek impoundment at Missouri State University's Darr Agricultural Center (see Kimmons, 2003; Anders, 2008 for further description of this habitat). Use of all specimens and procedures for this study was approved by the Missouri Department of Conservation, permit 13500 issued to the first author.

Mesh hoop traps were used for 3 separate turtle-trapping periods of $20 \mathrm{~h}$ ( 6 traps), $22.5 \mathrm{~h}$ (12 traps), and $24.5 \mathrm{~h}$ (12 traps). Pairs of RGS-baited and non-RGSbaited traps were simultaneously placed in the shallow waters of the impounded stream (Figure 2). Bait guards constructed from PVC piping had small, drilled openings to allow dispersal of scent molecules without any significant loss of bait (Figure 3 ). The traps were left in the water overnight because in a previous trapping study, most turtles of the target species ( $C$. serpentina) were captured between the hours of 1800 and 0900 (Smith and Iverson, 2004). Additionally, Plummer (1979) noted that the relative freshness of bait was not a factor in capturing $C$. serpentina, as both fresh bait and more putrid bait captured this species. At the end of each trapping period, pairs of traps were removed simultaneously to ensure that traps from the two treatment groups spent exactly the same amount of time in the water. Common Snapping Turtles (mean mass $\pm \mathrm{SE}=3.31 \pm 1.88 \mathrm{~kg}$ ) and other turtle species were processed on-site and released at the point of capture. Processing consisted of recording species, gender, carapace and plastron length (both to the nearest $1.0 \mathrm{~mm}$ ) and mass (nearest $0.01 \mathrm{~kg}$ ). Turtles were either previously marked from prior studies and recorded as such, or were marked after processing with grooves to the marginal scutes using a modified version of an identification system used by Cagle (1939). Additional turtle data were used for a separate pilot study on turtle community structure (Anders, 2008).

Comparison of the number of snapping turtles in RGS-baited traps versus non-RGS-baited traps was made using a two-tailed Mann-Whitney U-test (Minitab, 2010).

\section{RESULTS}

Laboratory Experiment - For latency to feed differences, there was no significant difference between control and RGS treatment groups (Wilcoxon test: $\mathrm{N}=8, \mathrm{~W}=$ $15.0, P=0.73$; Figure 4). Consumption time for the RGS treatment group was significantly greater than the con-

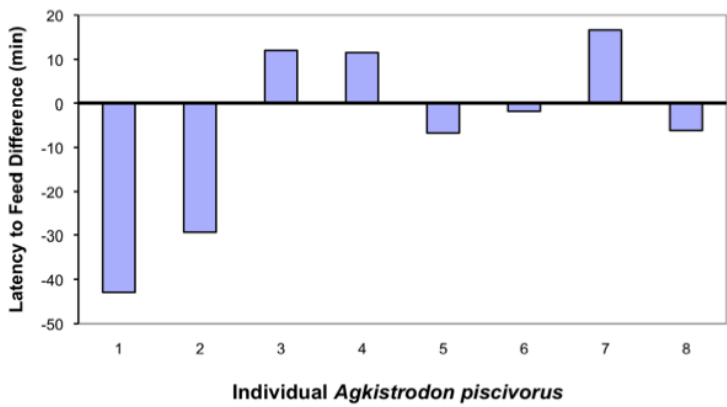

Figure 4. Latency to feed differences (RGS treatment - control treatment) for Agkistrodon piscivorus ( $\mathrm{P}=0.73$ ).
Table 1. Aquatic turtles caught in RGS-baited traps and nonRGS-baited traps. Numbers in parentheses indicate the range of turtle captures per trap (RGS = Rathke's gland secretions).

\begin{tabular}{lcccc}
\hline & \multicolumn{3}{c}{$\begin{array}{c}\text { Total Number } \\
\text { (Range Per Trap) }\end{array}$} & \\
\cline { 2 - 4 } Turtle Species & $\begin{array}{c}\text { RGS- } \\
\text { baited traps }\end{array}$ & $\begin{array}{c}\text { Non-RGS- } \\
\text { baited traps }\end{array}$ & P \\
\hline \hline Chelydra serpentina & $14(0-3)$ & $4(0-2)$ & $<0.05$ \\
Graptemys geographica & 0 & $2(0-1)$ & $\ldots$ \\
$\begin{array}{l}\text { Pseudemys concinna } \\
\text { Sternotherus odoratus }\end{array}$ & 0 & $1(0-1)$ & $\ldots$ \\
$\begin{array}{l}\text { Trachemys scripta } \\
\text { Total turtles }\end{array}$ & $14(0-3)$ & $1(0-1)$ & $\ldots$ \\
\hline
\end{tabular}

trol group (Wilcoxon test: $\mathrm{N}=8, \mathrm{~W}=33.0, \mathrm{P}=0.04$; Figure 5). No linear relationship between minnow mass and consumption time differences was detected (regression, $\mathrm{P}=0.75$ ).

Field Experiment - Significantly more Common Snapping Turtles were present in RGS-baited traps than in the non-RGS-baited traps (Mann-Whitney U-test: $U=180.0$, $\mathrm{P}=0.02$; Table 1 ). Fourteen Common Snapping Turtles (mean frequency per trap $\pm 1 \mathrm{SE}=0.93 \pm 0.88$ ) were captured in RGS-baited traps. Four Common Snapping Turtles (mean frequency per trap $\pm 1 \mathrm{SE}=0.26 \pm 0.59$ ) were captured in non-RGS-baited traps.

Although snapping turtle data were the primary focus of this study, turtles that are not predators of Sternotherus odoratus were also captured in the traps, and their data were noted for simple comparisons and observations (Table 1). Fourteen Sliders (Trachemys scripta) were captured in RGS-baited traps. Twenty $T$. scripta were captured in non-RGS-baited traps, along with 2 Common Map Turtles (Graptemys geographica), 1 Eastern River Cooter (Pseudemys concinna), and 1 Common Musk Turtle ( $S$. odoratus). When totaled and grouped by predator and non-predator status, 14 predator turtles (Common Snapping Turtles) and 14 non-predator turtles were captured in the RGS-baited traps. Four predator turtles (Common Snapping Turtles) and 24 non-predator turtles were captured in the non-RGS-baited traps (Table 1 ).

\section{DISCUSSION}

For the snakes in the laboratory experiment, the results do not support the hypothesis that the damage-released chemical alarm signals of Sternotherus odoratus function either as a predator repellent or attractant. The lack of response from the naive juvenile Cottonmouths to the chemical cue may be due to the use of a complex combination of chemical, visual, tactile, and thermal stimuli by viperid snakes when detecting prey (Vitt and Caldwell, 2009). Volatile chemical cues from prey animals detected by a snake's nasolfaction senses often lead to increased tongue-flicking and searching behavior that help locate

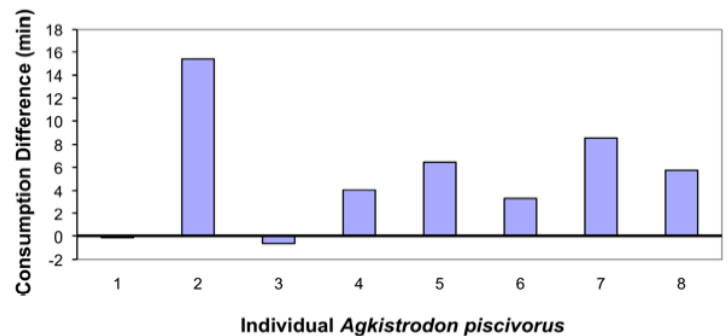

Figure 5. Consumption time differences (RGS treatment - control treatment) for Agkistrodon piscivorus ( $\mathrm{P}=0.04)$. 
prey and help detect more proximal nonvolatile cues (Ford and Burghardt, 1993). In addition, snakes can use different sensory cues in different habitat types or when searching for a particular prey taxa. For example, young garter snakes (Thamnophis) and Northern Water Snakes (Nerodia sipedon) begin foraging when they encounter water and may investigate fish prey using only visual cues (Drummond, 1985).

The design of the laboratory experiment may have contributed to the lack of an avoidance/attractant response to the turtle stimulus. For example, the availability of visual cues may have overridden any effect of the chemical cues. Concentration of chemical stimuli used in experimental predator-prey systems has been shown to influence the responses of some snake predators and so a stronger concentration of the stimulus may have induced a stronger response. Burghardt (1970) measured the attack responses of Butler's Garter Snakes ( $T$. butleri) to different concentrations of nightcrawler extract and found that attack scores of snakes significantly increased when stronger concentrations of the extract were used.

Snakes are well-known for processing odor molecules collected via tongue-flicking with an extremely sensitive vomeronasal (Jacobson's) organ, and they also use taste buds, positioned in tissue along the tooth rows after prey items have been seized (Greene, 1997). Thus, it is likely that chemical cues from prey items influence handling or consumption times during the subjugation phase of a predation event. Although the possibility of a topical effect of the RGS on the mouth of a snake predator could also influence handling time of the prey this specific factor was not investigated in our study. In this study, the significantly greater consumption times for RGS-treated prey items, suggest that the RGS may lengthen the subjugation phase of a predation sequence, allowing the turtle more time for escape from the snake's jaws.

In the field experiment, Common Snapping Turtles were attracted to, and not deterred by, the RGS of Common Musk Turtles. Although the emission of chemical signals to attract predators may seem counterintuitive, the musk turtle's odorous secretions, like the auditory distress calls of birds (Perrone, 1980; Hogstedt, 1983; Koenig et al., 1991) and mammals (Sherman, 1985), and the damage-released chemical alarm cue of fishes (Mathis et al., 1995), is frequently produced only when the signal's sender is in dire circumstances (Ernst and Lovich, 2009). The attraction of a secondary predator would benefit the sender if the secondary predator were to interfere with the primary predator. For example, Chivers et al. (1996) concluded that secondary predators that are attracted to the alarm pheromone of Fathead Minnows (Pimephales promelas) disrupt the predation event, which allows the prey an opportunity to escape. Similarly, Mathis et al. (1995) reported observations in laboratory tanks of secondary pike predators interfering with primary pike predators by attempting to grab prey minnows already seized by the first pike, by colliding with the first pike, or by biting the first pike around the opercula, which caused it to open its mouth giving the prey minnow an escape opportunity. Similar encounters are likely to occur between two snapping turtles in close proximity to one another in the presence of a small prey item. On several occasions while removing a baited hoop trap from an aquatic habitat, we have observed captured Common Snapping Turtles aggressively biting the limbs of other snapping turtles caught in the same baited trap.

The use of a chemical signal by $S$. odoratus to influence predation by an aquatic predator is highly plausible considering that aquatic environments are ideal for the dispersal of chemical cues. Chemical signals are more persistent than auditory and mechanical signals, and are especially useful in conditions where vision is obscured by turbid waters or dense vegetation (Dodson et al., 1994, Wisenden, 2000). Such limitations on vision would be common in the highly vegetated littoral zones most often utilized by Common Musk Turtles (Rowe et al., 2009). Visual cues would also be less useful than chemical cues during the low-light periods when crepuscular foragers like $S$. odoratus are most active. Mahmoud (1968) found Common Musk Turtles to be most active from 0400 to $1020 \mathrm{~h}$ and from 1720 to $2100 \mathrm{~h}$.

While the exact function of the Common Musk Turtle's RGS is still unclear, demonstrating that a predator of this species is attracted to these chemical cues in a field study, and that another predator's ingestion efficiency may be reduced by chemical influence in a laboratory setting are important steps in understanding the role of chemical production in this species. These results further emphasize the complex nature of various signaling mechanisms used in vertebrate predator-prey systems.

\section{ACKNOWLEDGMENTS}

We thank Dr. Alicia Mathis for her invaluable assistance in experimental design, statistical procedures and for her encouragement and guidance. We thank Dr. Brian Greene for helping with statistics and for the use of his laboratory. We also thank Ben Anders, Kristy Marson, Ryan Combs, Diana Mullich, Holly Monroe, and Evan Menzel for their fieldwork assistance. The Graduate College of Missouri State University and the Department of Biology provided generous funding for this project. Thanks to Ben Fuqua for permission to access South Creek at the Darr Agricultural Center, and to the Missouri Department of Conservation for aiding with necessary permits. This paper is drawn from a M.S. thesis presented by the first author to the Graduate Faculty of the Biology Department, Missouri State University.

\section{LITERATURE CITED}

Anders, B. 2008. Influence of ultraviolet light, righting response, and community structure in aquatic turtles. Master's thesis, Missouri State University, Springfield, MO.

Britson, C. A. and W. H. Gutzke. 1993. Antipredator mechanisms of hatchling freshwater turtles. Copeia 1993: 435-440.

Burghardt, G. M. 1970. Chemical perception in reptiles. In J. W. Johnson, D. G. Moulton, and A. Turk (eds.), Communication By Chemical Signals, pp. 241-308. Appleton-Century-Crofts, New York.

Cagle, F. R. 1939. A system for marking turtles for future identification. Copeia 1939: 170-173.

Chivers, D. P., G. E. Brown, and J. F. Smith. 1996. The evolution of chemical alarm signals: Attracting predators benefits alarm signal senders. The American Naturalist 148: 649-659.

Chivers, D. P. and R. J. F. Smith. 1998. Chemical alarm signaling in aquatic predator-prey systems: A review and prospectus. Écoscience 5: 338-352.

Dodson, S. I., T. A. Crowl, B. L. Peckarsky, L. B. Kats, A. P. Covich, and J. M Culp. 1994. Non-visual communication in freshwater benthos: An overview. Journal of the North American Benthological Society 13: 268-282.

Drummond, H. 1985 . The role of vision in the predatory behaviour of natricine snakes. Animal Behaviour 33: 
206-215.

Ehrenfeld, J. G. and D. W. Ehrenfeld. 1973. Externally secreting glands of freshwater and sea turtles. Copeia 1973: 305-314.

Eisner, T., W. E. Conner, K. Hicks, K. R. Dodge, H. I. Rosenberg, T. H. Jones, M. Cohen, and J. Meinwald. 1977. Stink of stinkpot turtle identified: $\omega$-phenylalkanoic acids. Science 196: 1347-349.

Endler, J. A. 1986. Defense against predators. In M. Feder and G. Lauder (eds.), Predator-Prey Relationships, Perspectives and Approaches from the Study of Lower Vertebrates, pp. 109-134. The University of Chicago Press, Chicago, IL.

Ernst, C. H. 1986. Ecology of the turtle, Sternotherus odoratus, in southeastern Pennsylvania. Journal of Herpetology 20: 341-352.

Ernst, C. H. 1992. Venomous Reptiles of North America. Smithsonian Institution Press, Washington, D.C.

Ernst, C. H. and J. E. Lovich. 2009. Turtles of the United States and Canada. 2nd ed. The John Hopkins University Press, Baltimore, MD.

Ford, N. B. and G. M. Burghardt. 1993. Perceptual mechanisms and the behavioral ecology of snakes. In R. A. Seigel and J. T. Collins (eds.), Snakes: Ecology and Behavior, pp. 117-154. McGraw-Hill Inc., New York.

Green, M. D. 2006. Nest emergence and chemosensory mediated predator avoidance: two studies of behavior in the red-eared slider (Trachemys scripta elegans). Master's thesis, Missouri State University, Springfield, MO.

Greene, H. W. 1997. Snakes: The Evolution of Mystery in Nature. University of California Press, Berkley, CA.

Gloyd, H. K. and R. Conant. 1990. Snakes of the Agkistrodon Complex, a Monographic Review. Society for the Study of Amphibians and Reptiles. St. Louis, MO.

Hagman, M. and R. Shine. 2008. Understanding the toad code: behavioral responses of cane toad (Chaunus marinus) larvae and metamorphs to chemical cues. Austral Ecology 33: 37-44.

Halpern, J., N. Schulman, and M. Halpern. 1986. Earthworm alarm pheromone is a garter snake chemoattractant. Chemical Senses 11: 607-608.

Hews, D. K. 1988. Alarm response in larval western toads, Bufo boreas: Release of larval chemical by a natural predator and its effect on predator capture efficiency. Animal Behaviour 36: 125-133.

Hogstedt, G. 1983. Adaptation unto death: function of fear screams. The American Naturalist 121: 562570.

Jackson, J. F. 1990. Evidence for chemosensor-mediated avoidance in musk turtles. Copeia 1990: 557-560.

Johnson, T. R. 2000. The Amphibians and Reptiles of Missouri. 2nd ed. Missouri Dept. of Conservation, Jefferson City, MO.

Kimmons, J. 2003. Seed dispersal by aquatic turtles. Master's thesis, Southwest Missouri State University, Springfield, MO.

Koenig, W. D., M.T. Stanback, and P. N. Hooge. 1991. Distress calls in the acorn woodpecker. Condor 93: 637-643.

Legler, J. M. 1960. A simple and inexpensive device for trapping aquatic turtles. Utah Academy of Science Proceedings 37: 63-66.

Lewis, C. H., S. F. Molloy, R. M. Chambers, and J. Davenport. 2007. Response of Common Musk Turtles (Sternotherus odoratus) to intraspecific chemical cues. Journal of Herpetology 41: 349-353.

Mahmoud, I. Y. 1968. Feeding behavior in kinosternid turtles. Herpetologica 24:300- 305.

Marvin, G. A. and V. H. Hutchison. 1995. Avoidance response by adult newts (Cynops phyrrhogaster and Notophthalmus viridescens) to chemical alarm cues. Behaviour 132:95-105.

Mathis, A. and R. J. F. Smith. 1993. Chemical alarm signals increase the survival time of fathead minnows (Pimephales promelas) during encounters with northern pike (Esox lucius). Behavioral Ecology 4:260-265.

Mathis, A., D. P. Chivers, and R. J. F. Smith. 1995. Chemical alarm signals: predator deterrents or predator attractants? The American Naturalist 145:994-1005.

Minitab, Inc. 2010. MINITAB Statistical Software, Release 15 for Windows. State College, PA.

Moll, D. and E. O. Moll. 2004. The Ecology, Exploitation, and Conservation of River Turtles. Oxford University Press, New York.

Monroe, H. J. 2009. Behavioral response of Sternotherus odoratus to conspecific and predatory chemosensory cues. Master's thesis, Missouri State University, Springfield, MO.

Mullich, D. E. 2007. Variation in defensive behaviors of the western Cottonmouth (Agkistrodon piscivorus) as a result of temperature, size, and reproductive condition. Master's thesis, Missouri State University, Springfield, MO.

Perrone, M., Jr. 1980. Factors affecting the incidence of distress calls in passerines. Wilson Bulletin 92:404408.

Plummer, M. V. 1979. Collecting and marking. In M. Harless and $\mathrm{H}$. Morlock (eds.), Turtles: Perspectives and Research, pp. 45-60. John Wiley \& Sons, New York.

Punzo, F. and L. Alton. 2002. Evidence for the use of chemosensory cues by the Alligator Snapping Turtle, Macroclemys temminckii, to detect the presence of musk and mud turtles. Florida Scientist 65:134-138.

Radhakrishna, G., C. C. Q. Chin, F. Wold, and P. J. Weldon. 1989. Glycoproteins in Rathke's gland secretions of loggerhead (Caretta caretta) and Kemp's ridley (Lepidochelys kempi) sea turtles. Comparative Biochemistry and Physiology 94B:375-378.

Rostal, D. C., J. A. Williams, and P. J. Weldon. 1991. Rathke's gland secretions by loggerhead (Caretta caretta) and kemp's ridley (Lepidochelys kempi) sea turtles. Copeia 1991:1129-1132.

Rowe, J. W., G. C. Lehr, P. M. McCarthy, and P. M. Converse. 2009. Activity, movements and activity area size in stinkpot turtles (Sternotherus odoratus) in a Southwestern Michigan Lake. The American Midland Naturalist 162:266-275.

Seifert, W. E. Jr., S. W. Gotte, T. L. Leto, and P. J. Weldon. 1994. Lipids and proteins in the Rathke's gland secretions of the North American mud turtle (Kinosternon subrubrum). Comparative Biochemistry and Physiology 109B: 459-463.

Semlitsch, R. D. and J. W. Gibbons. 1989. Lack of largemouth bass predation on hatchling turtles (Trachemys scripta). Copeia 1989: 1030-1031.

Sherman, P. W. 1985. Alarm calls of Belding's ground squirrels to aerial predators: Nepotism or self-preservation? Behavioral Ecology and Sociobiology 17: 313-323.

Smith, R. J. F. 1992. Alarm signals in fishes. Reviews in Fish Biology and Fisheries 2: 33-63. 
Smith, G. R. and J. B. Iverson. 2004. Diel activity patterns of the turtle assemblage of a northern Indiana lake. The American Midland Naturalist 152:156-164.

Staton, M. A. 1978. "Distress calls" of crocodilians whom do they benefit? The American Naturalist 112:327-332.

Tester, A. L. 1963. The role of olfaction in shark predation. Pacific Science 17:145- 170.

Vitt, L. J. and J. P. Caldwell. 2009. Herpetology. 3rd ed. Academic Press, Burlington, MA.

Weldon, P. J. 1983. The Evolution of Alarm Pheromones. In D. Müller- Schwarze and R. Silverstein (eds.), Chemical Signals In Vertebrates 3, pp. 309-312. Plenum, New York.
Weldon, P. J. and M. J. Tanner. 1990. Lipids in the Rathke's gland secretions of hatchling loggerhead sea turtles (Caretta caretta). Copeia 1990:575-578.

Williams, C. R., E. D. Brodie Jr., M. J. Tyler, and S.J. Walker. 2000. Anitpredator Mechanisms of Australian Frogs. Journal of Herpetology 34: 431-443.

Wisenden, B. D. 2000. Olfactory assessment of predation risk in the aquatic environment. Philosophical Transactions of the Royal Society of London B: Biological Sciences 355: 1205-1208.

Wisenden, B. D. and T. A. Thiel. 2002. Field verification of predator attraction to minnow alarm substance. Journal of Chemical Ecology 28: 433-438. 